Faculty of Law, Sakarya University,

\title{
CAPITAL COMPANIES' OBLIGATION TO SET UP A WEBSITE: AN INSTRUMENT FOR TRANSPARENCY AND CORPORATE GOVERNANCE IN TURKISH COMPANY LAW ${ }^{* *}$
}

\begin{abstract}
One of the most noteworthy innovations in the new Turkish Code of Commerce, ${ }^{1}$ published in 2011, was the capital companies' obligation to set up a website. It was aimed to institutionalize the companies, ensure that local and foreign investors have the right to get information about the company, and ensure transparency of corporate governance in view of meeting the requirements of harmonization of Turkish Law with European Union Law. Before the Code entered into force on the 1st July 2012, the legislator had shifted on the scope and sanctions of this obligation, especially in response to the reactions from small-scale capital companies. While all capital companies were initially obliged to set up a website, o the last amendments envisaged thatthis obligation applies only to capital companies which are subject to independent audit. The obligation of capital companies to set up a website is regulated in Article 1524 of the Turkish Code of Commerce, which prescribes that only the capital companies which are subject to independent audit are obliged to set up a company website. Companies must fulfill their obligations by opening a website within three months from the date of trade company registration, publishing a certain portion of the site and posting company announcements and notices, as prescribed by the law. In case a company fails to comply with these obligations, administrative and penal sanctions will be applied.
\end{abstract}

Key words: private limited companies, Turkish company law, Turkish commercial law, website obligation, Turkish Code of Commerce.

\footnotetext{
*avmyasan@yahoo.com

${ }^{* *}$ This paper was presented at the International Scientific Conference "Law in the context of addressing the Challenges of the Contemporary World", held at the Faculty of Law, University of Niš, on $13^{\text {th }}-14^{\text {th }}$ April 2018.

1 Turkish Code of Commerce,Official Gazette No. 27846 dated 14.02.2011.
} 


\section{Introduction}

The topic of this paper is the capital companies' obligation to set up a website in Turkish Company Law. The topic was chosen with the aim to address the Conference subtopic: "Modern Technologies and Law: application, protection and liability".The Turkish Code of Commerce (hereinafter: TCC) was enacted in 2011 and came into force in 2012. This Code had significant effects on the institutions related to commercial law and company law in particular. One of the targeted effects was to supply the legal regime with transparency and corporate governance. The webpage obligation of capital companies was just one of the instruments to achieve the legislator's purpose. However, after introducing the amendments -as a result of the legislator's populist approach,the TCC moved away from the starting point in terms of the "ratio legis" of the codification.

\section{Regulation of the Web Page Obligation as a Reform in the TCC}

\subsection{The Process of Regulating theObligation}

The Turkish Commercial Code (TCC) No. 6102 entered into force in 01.07.2012 as a result of 12 years' legislativeeffort in this area.The Code was just one of more than ten significant codification reforms which were prepared and came into force with enthusiasm and motivation, as the request generated by the start of accession negotiations in 2005 between Turkey and the European Union (Bilgili, Demirkapı, 2013:8). As stated in the Preamble, the TCC was aimed to reach a commercial and company law level which was compatible with the European Union regulations, in compliance with the investment and competition climate. For this reason, the corporate governance principle envisaged in the TCC was intended to be the governing principle in the regulation of companies, and especially in terms of capital companies. Transparency, accountability, independent auditing and supervision by the state were accepted as the key concepts and institutions of the TCC and, in particular, the legal regime related to corporate and company law (Kendigelen, 2016: 596).

An important innovation in the legal regime brought by the TCC was the requirement or obligation for capital companiesto set up a website (Ylldız, 2007: 51). As a matter of fact, in the Final Provisions, under the heading "Electronic Transactions and Information Society Services", Article 1524 of the TCC regulates an obligation of each capital company to set up a website (Pulaşll, 2014: 740 ). In addition, the provisions on this obligation aredispersed and located in various other articles, thus lacking systematics (Kendigelen, 2016: 597). However, in accordance with Article 1524 para.4 of the TCC, the Ministry of Customs and Trade has been given the authority and duty to issue regulation in order to 
clarify the implementation of the website obligation. Accordingly, the Ministry published "the Regulation on Websites to be Set up by Capital Companies" in the Official Gazette on 31 May 2013.

\subsection{The Essentials of Website Obligation}

\subsubsection{Criteria of the Time to Fulfil the Obligation}

According to Article 1524 (para.1) of the TCC, all capital companies are obliged to set up a website within three months following the registration of the company in the trade registry. It is also obligatory to allocate a certain part of the website for the publication of the company announcements, which must be made by the legal personality of the company as required by the law (Moroğlu, 2012: 399). The company's website shall be registered in the trade registry but the registration does not have a founding effect; it only has explanatory effect (Pulaşli, 2014: 563).

The contents to be published on the website shall be posted on the website within five days as the latest, unless another exceptional period is specified in the TCC. The five-day period start from the date of the transaction or the event which are the basis for posting the website contents. In case of registration or announcement, the five-day period shall be processed from the date of registration in trade registry or announcement on the Turkish Trade Registry Gazette(TTRG) website. The content that should be published in the period from the establishment of the company to the opening of the website is also put on the page at the time when thewebsiteis activated. The sanction for non-compliance with this obligation is the cancellation of the decisions of the company's General Assembly, which is the basis for posting the content on thewebsite. In addition, the requirement for the annulment of the company's General Assembly decisionshas to be observed (Moroğlu, 2012: 399, 400).

\subsection{Obligatory Website Content}

The legal personality of the company is obliged to include information about the company's Board of Directors and auditors, the amount of the company's promised and paid capital, the financial statements, merger agreements, and reports in case of division and merger. In addition, it is also compulsory that the decisions regarding the dissolution of the company and the cancellation of the General Assembly resolutions, the decrease in the number of the shareholders of the company and any changes in the company agreements are published on the company's web site (Kendigelen, 2016: 597). 
Information on all other issues referred to in Article 6 of the Regulation on Websites to be set up by Capital Companies $(2013)^{2}$ shall also be posted on the website.Hence, it is necessary to examine the provisions of the Regulation related to the content of the capital companies' website. The list of required information which companies are obliged to post on the website is specified in Article 6 of the Regulation, as follows:

- The company's MERSIS number, trade name, registered centre, the amount of promised and paid capital, the chairman and members of the Board of Directors in joint stock companies, and the directors in limited liability companies;

- In case a legal entity is elected as a member of the Board of Directors in a joint stock company or as a director in a limited liability company, in addition to the information of legal personality, the posted information shall include the name and surname of the natural person who is selected on behalf of the legal personality, the information that the natural person representative is also registered and announced, the MERSIS code of the selected legal personality as director, trade name and registered office of the legal personality;

- The name, surname, title, place of residence/registered office and,in casethere is a branch office, the registration information of the branch.

In case of any changes in the aforementioned contents, the new version shall be published on the website at the date of the change (Art. 6.2 Regulation). In addition, Article 6.3 of the Regulation contains a long list of the elements related to the website obligation. ${ }^{3}$

Unless a longer period is stipulated in the TCC and other applicable administrative regulations, such as the Ministry Regulation (2013), the content posted on the company's website shall remain on the website for a period of at least six months from the date on which it was placed. Otherwise, it is assumed that the content is not placed and that the website obligation has not been fulfilled (Article 1524 para. 5 TCC).

\subsection{The Respondent of the Website Obligation}

It is the responsibility of the company directors and the members of the company's Board of Directors to place the content on the website within the required period, which is specified according to different circumstances in the Regulation

2 Regulationon Websites to be Set up by Capital Companies, Official Gazette, No.28663, 31 May 2013.

3 For more detail, see the specific provisions on the content of the list regulated in Article 6. 3 of the Regulation. 
(2013).Failure of the company directors and members of the Board of Directors to comply with the prescribed obligations leads to their liability for violation of the law (Article 1524 para. 2 TCC)

According to Article 1524 para.3 TCC, the section of the website dedicated to information society services must be accessible to all, even though there is not a specific benefit. The right of access cannot be limited to the use of any records, or be bound by any conditions, such as being relevant or of interest. If the right of access is removed or limited by the decision of the company management or its General Assembly, everyone can file a lawsuit to remove this obstacle (Bahtiyar, 2017: 164).In addition, the claimant can file a compensation claim against the respondents of the obligation (Üçışık, Çelik, 2013: 509).

Another consequence of the failure of company directors and members of the Board of Directors to comply with the envisaged website obligation is criminal responsibility (Article 1524 para. 2 TCC) because these violations are described as offences which result in criminal sanctions(Bilgili, Demirkapı, 2013: 605). According to Article 562 para.12 TCC (criminal liability), the members of the company managing body who do not setup the websitewithin the prescribed period shall be punished with a judicial fine for a period ranging from one hundred to three hundred days (Bahtiyar, 2017: 386). Under the same article, members of the executive body who do not duly post the content on the website shall be punished with a judicial fine of up to one hundred days. Prosecutors are both authorized and obliged to initiate criminal investigation or proceedings with or without any notice. The prosecution for these criminal offences is not subject to a complaint (Kayar, 2015: 414).

In Turkish Law, the judicial fine is regulated in Article 52 of the Turkish Criminal Code, ${ }^{4}$ No. 5237.Under this Article, the judicial fine may not be awarded for less than five days and no more than seven hundred and thirty days in cases not otherwise specified in the Code. The amount of the judicial fine shall be determined by taking into account the personal and economic characteristics of the convict, the determination of which shall be at least twenty and at most one hundred Turkish Liras. The amount, calculated by multiplying the number of full days determined by the court by the amount that is established for one day, shall be paid to the State treasury. The exact number of days taken as a basis for determining the judicial fine and the amount recognized as a day equivalent are shown separately in the court decision. According to the aforementioned provisions, the upper limit of the judicial fine that can be issued for a violation of the website obligation is $30.000 \mathrm{TL}$.

4 Turkish CriminalCode, No. 5237, Official Gazette, 26.09.2004 No: 25611. 


\section{Regulations in Comparative Law}

In the UK company law, the obligation of the companies to setup a website is considered as one of the most important requirements of the corporate governance principle. According to the related provisions of Companies Act 2006 (CA), the company website is considered as a condition that must be fulfilled for the establishment of a company (Hannigan, 2009: 22, 23). In addition, the company has to fulfil the requirements related to auditing and calling the general assembly meetings by publishing the information on the company's website (Kershaw, 2009: 97). Moreover, the company's general assembly decisions must be published on the website to ensure their binding character for all shareholders (Girvin, Frisby, Alastair, 2010: 469). For this reason, in the UK legal system, companies are obliged to open the website in order to complete the establishment of the company; they are also obliged to actively use the website and make announcements on the company management, supervision and decisions (Hannigan, 2009: 374). These obligations are accepted as a requirement of the corporate governance principle. In addition, the website obligation has been specifically addressed in the relevant $\mathrm{CA}$ articles as a reflection of the principles of both accountability and liability. Another significant characteristic of this obligation in the UK company law is that all types of companies subject to the CA are obliged to fulfil the requirements related to website provisions without any discrimination. Thus, the UK legislator aims to ensure the main principles of modern company law and the validity of company law codifications (Girvin, Frisby, Alastair, 2010: 494, 495).

In German company law, the companies' obligations to setup a website are regulated in the disaggregated provisions of the Stock Corporation Act (Aktiengesetz -AktG) (Pöpken, Richter, 2012: 72). The company websiteobligation concerns the right to obtain information and copies of the contracts made after the establishment. Accordingly, it is not possible for the partners to request a copy of these contracts from the company if a copy of a contract has been made after the establishment on the company's web page. Invitations from the company's general assembly meetings should include information on the company's web site too (Goette, Habersack, Kalls, 2018: Rn.1-15). In fact, posting the announcement of the general assembly meetings on the company's website is a precondition for the call to be legally valid. The web page of the announcements to be made by the company has gained special importance in case of a joint stock company operating in the capital market. Article 124a) AktG includes a special provision regarding the announcement on the company's webpage (Goette, Habersack, Kalls, 2018: 1-15). The company's webpage plays an active role in implementing the proposals for the decisions taken by the shareholders at the general 
assembly and their subordination to the Corporate Governance Code (Pöpken, Richter, 2012: 79-83).

In Serbian company law, the Company Act envisages the obligation of limited liability companies and joint stock companies to publish on its website or on the website of registered economic entities a notice on the taken legal action or completed legal transaction, with relevant facts and description of the business activity, within a period of 15 days from the conclusion of the legal transaction (Article 66 para. $9 \mathrm{CA}){ }^{5}$ The announcements posted on the company website have a special significance; they are a prerequisite that ensures the validity of the corporate governance principles. Thus, it is imperative that the guidelines for corporate governance areposted on the company's website (Art 335 CA on general assembly meetings, Article $356 \mathrm{CA}$ on publishing the general assembly decisions).All documents, decision and reports should be made public and accessible to the shareholders (Article $465 \mathrm{CA}$ ).

\section{The Legislator's Expectations about the Website Obligation, and assessment on whether the expectations have been met to date}

One of the innovations that can be described as a reform in the Turkish Commercial Code (TCC) is the obligation of capital companies to setup a website. The legislator aimed to establish a law of competitiveness which is suitable for the European Union investment climate and to ensure validity of the legal regime for the capital companies in compliance with the principles of transparency and accountability. When the Code was enacted in the Turkish Grand National Assembly (TGNA) and published in the Official Gazette, the purpose-oriented provisions were validated. One of these provisions is the capital company's internet page obligation. Transparency will be ensured at the highest level through the introduction of the website obligation in company law. In this way, the information related to the company, the company's statements, calls, explanations, announcements, prepared documents, reports, financial statements and answers to questions will be made easily accessible to everyone.

For these reasons, in the original version of the Turkish Commercial Code,enacted and published in the Official Gazette in 2011,all the capital companies were obliged to setup a website. All joint stock companies, limited liability companies and cooperative companies with shares were also obliged to establish a website without any distinction in terms of the size or scales of business. On the other hand, only two days before the Code came into force on 01.07.2012, radical

5 The Company Act, Official Gazette of RS no. 36/2011, 99/1011, 83/2014, 5/2015 and 44/2018 
amendments were made to the TCC by enacting the Code No. $6335^{6}$. One of the enacted amendments was related to the scope of the capital companies subject to the obligation to set up a website.

According to the last version of the Code, after introducing the significant last minute amendments in 2012, all capital companies were not subject to the obligation to set up a website, but only the capital companies which are subject to independent auditing. As a matter of fact, the companies subject to independent audit are only joint stock companies, under the criteria determined by the Council of Ministers, and the number of joint-stock companies which meet these criteria does not exceed 5.000 for the year 2018. According to the TCC and the legislative decree on Public Oversight, after the updated criteria for 2018, a capital company has to meet at least two of the following criteria in order to be subject to independent auditing and, hence, the obligation of opening a website(Șener, 2017: 434):

1. Total assets of 40 million TL and more.

2. Annual net sales revenue of 80 million TL and more.

3. Number of employees: two hundred and more.

In the Turkish trade practice, the number of capital companies that can meet the criteria underlined above does not exceed 5.000 companies for the year 2018. In line with the objectives of the Code specified in the Preamble of the first original version of the Turkish Commercial Code, all capital companies, including a total of about 850.000 public limited and private limited companies, were subject to the website obligation.

The main reason for introducing amendments that changed the scope of companies subject to the website obligation was the objections coming from the actors in Turkish commercial life. In particular, the Union of Chambers and Commodity Exchanges of Turkey tried to manipulate the codification and Turkish Company Law reform. Despite the fact that the Turkish Commercial Law doctrine stated that the original version of the Code should have been kept, the Turkish legislator resorted to a populist approach. Unfortunately, due to the populist approach, the Turkish Code of Commerce (TCC) has been amended 17 times in the past six years, since 2012 to date. By all these amendments, the TCC moved away from the starting pointenvisaged in the original version of the TCC. For this reason, it is considered that the legislative efforts to codify the commercial law matter have ended with failure and disappointment. In terms of the normative framework related to the obligation of capital companies to set up a web page, we need to return to the original first version of the Code. Thus, as envisaged

6 Code No. 6335, Official Gazette, 30.06.2012 No: 28339. 
in the original version of the Code, all capital companies need to be subject to the website obligation without exception and discrimination.

\section{Conclusion}

As in all modern company law regulations, the obligation of capital companies to set up a website is regulated as one of the key principles of corporate governance, envisaged in the European Union regulations. In the effort to harmonize its legislation with EU law, Turkeyadopted the 2011 Turkish Code of Commerce (TCC), which prescribed the obligation to all capital companies to set up a website andmake the information on legal transactions accessible to shareholders and general public. The content of the obligation and the scope of the respondents were originally taken from the comparative law resources. However, after amending the TCC by the Code No. 6335, the scope of the companies which were subject to this obligation was narrowed. In spite of the legislator's original intention to subject at least 850.000 capital companies to this obligation, after all these amendments, the scope of companies that are obliged to set up a website has been reduced only to public limited companies which are subject to independent audit.In conclusion, the codification efforts have resulted in aprofound disappointment, especially for company lawyers.

\section{References}

Bahtiyar, M., (2017). Ortaklıklar Hukuku. İstanbul: Beta Yayınevi

Bilgili, F., Demirkapı, E., (2013). Şirketler Hukuku. Bursa: Dora Yayınevi

Girvin, S., Frisby, S., Alastair, H., (2010). Charlesworth's Company Law. London: Sweet \& Maxwell

Goette, W., Habersack, M., Kalls, S. (2018). Münchener Kommentar zum Aktiengesetz Band 3, München: Verlag C.H. Beck

Hannigan, B., (2009). Company Law. New York: Oxford Press

Kayar, İ., (2015). Ticaret Hukuku. Ankara: Seçkin Yayinevi

Kendigelen, A., (2016). Türk Ticaret Kanunu Değişiklikler, Yenilikler ve İlk Tespitler. İstanbul: XII Levha

Kershaw, D. (2009). Company Law in Context. New York: Oxford Press

Moroğlu, E., (2012). 6102 Sayılı Türk Ticaret Kanunu Değerlendirme ve Öneriler. İstanbul: XII Levha

Pöpken, K., S., Richter, H., P., (2012). Gesellschafts-Recht. Danischenhagen: Richter Verlag 
Pulaşl1, H., (2014). Şirketler Hukuku Şerhi. Ankara: Adalet Yayınevi

Şener, O. H., (2017). Ortaklıklar Hukuku. Ankara: Seçkin Yayınevi

Üçışık, G., Çelik, A., (2013). Anonim Ortaklıklar Hukuku. Ankara: Adalet Yayınevi

Yıldız, Ş., (2007). Limited Şirketler Hukuku. Ankara: Arıkan Yayınevi

Türk Ticaret Kanunu, No. 6102, 13.1.2011, T.C. Resmî Gazete,14.02.2011, Sayı : 27846 (Turkish Code of Commerce, No. 6102, of 13.1.2011, Official Gazette,14.02. 2011, ID: 27846); available at: http://www.resmigazete.gov.tr/eskiler/2011/02/20110214-1-1.htm, accessed 30.10.2018

Türk Ceza Kanunu,No. 5237, T.C. Resmî Gazete, 26.09.2004, ID: 25611; available in Turkish at: https://www.ilo.org/dyn/natlex/docs/ELECTRONIC/77393/96373/ F2120749307/TUR77393\%20Turk.pdf;Turkish Criminal Code, No. 5237,Official Gazette, 26.09.2004; available in English at: https://www.ilo.org/dyn/natlex/ docs/ELECTRONIC/77393/96372/F1927486451/TUR77393\%20English\%202. pdf

Türk Ticaret Kanunu ile türk ticaret kanununun yürürlüğü ve uygulama şekli hakkında kanunda değişiklik yapılmasına dair kanun kanun No. 6335, 26/6/2012Resmî Gazete,30.06.2012, No: 28339. (Law No. 6335, Amending the Turkish Commercial Code of 26.6. 2012, Official Gazette)Available in Turkish at: http://www.resmigazete.gov.tr/eskiler/2012/06/20120630-5.htm

Sermaye Şirketlerinin Açacakları İnternet Sitelerine Dair Yönetmelik, Resmi Gazete, 31.05.2013, Say1: 28663(Regulation regarding Websites to be Set up by Capital Companies, Official Gazette, No. 28663, 31 May 2013); available in Turkish at: http://www.resmigazete.gov.tr/eskiler/2013/05/20130531-15.htm, accessed 12.11.2018

Zakon o privrednim društvima (Company Act), Službeni glasnik RS br. 36/2011, 99/1011, 83/2014, 5/2015,44/2018; available at: https://www.paragraf.rs/ molovani/zakon-o-privrednim-drustvima.html, accessed 30.10.2018 
Др Mustafa Yasan, Доцент, Правни факултет, Сакарија Универзитет, Сакарија, Турска

\title{
ОБАВЕЗА ДРУШТВА КАПИТАЛА ДА ПОСТАВИ ИНТЕРНЕТ СТРАНИЦУ, КАО ИНСТРУМЕНТ ЗА ПОСТИЗАЫЕ ТРАНСПАРЕНТНОСТИ КОРПОРАТИВНОГ УПРАВЉАЫА У ТУРСКОМ КОМПАНИЈСКОМ ПРАВУ
}

\begin{abstract}
Резиме
Једна од најзначајнијих новина у новом турском Закону о трговини, објављеном у Службеном гласнику 2011. године, је обавеза сваког друштва капитала да креира и постави званичну интернет страницу (веб-сајт). Ова одредба имала је за циљ институционализацију предузећа, обезбеђивање права домаћим и страним инвеститорима да добију адекватне информације о компанији, као и обезбеђивање веће транспарентност у контексту испуњавања преузете обавезе усклађивања турског законодавства са правом Европске уније. Пре него што је Закон о трговини ступио на снагу 1. јула 2012. године, законодавац је променио оквир и санкције за кршење ове обавезе, као одговор на реакиије мањих компанија. Иако су иницијално сва друштва капитала имала обавезу да поставе инетернет странице, према последњим изменама овог закона та обавеза је прописана само за друштва капитала која подлежу независној (екстерној) ревизији. Обавеза ових компанија да креирају и поставе интернет странице регулисана је чланом 1524. Закона о трговини Републике Турске, који прописује да су друштва капитала која подлежу независној ревизији дужна да израде и поставе интернет страницу. Ове компаније морају испунити своје обавезе отварањем интернет странище у року од три месеца од дана регистрације трговинског друштва и одређивањем дела вебсајта за постављање обавештења и најавау складу за законом. Уколико компанија не испуни прописане обавезе, примењују се административне и кривичне санкције.
\end{abstract}

Кључне речи: Турски Закон о трговини, друштаво капитала, обавеза постављања интернет странище, приступ информацијама, транспарентност, административне и кривичне санкције. 
